\title{
A COMPARISON OF EPIDEMIOLOGIC, HISTOLOGIC, AND VIROLOGIC STUDIES ON HODGKIN'S DISEASE IN WESTERN KENYA AND NAGASAKI, JAPAN
}

\author{
MASAKO KUSUDA, KAN TORIYAMA, NOAH O. KAMIDIGO, AND HIDEYO ITAKURA \\ Department of Pathology, Institute of Tropical Medicine, Nagasaki University, Nagasaki, Japan; Department of Histopathology, \\ Rift Valley Provincial General Hospital, Nakuru, Kenya
}

\begin{abstract}
Rapid progress in molecular technologies has enabled the detection of several oncogenic viruses in various types of tumors. The pathogenesis of Hodgkin's disease is suggested to have a strong association with EpsteinBarr virus (EBV). However, Hodgkin's disease related to EBV shows a wide geographic variation in epidemiology. These variations among different populations suggest an interaction of environmental factors and a direct role of EBV infection. Therefore, we performed a comparative study on epidemiologic, histologic, and virologic features of Hodgkin's disease among those in the western part of Kenya and in Nagasaki, Japan. The age distribution of Hodgkin's disease showed a distinct peak in the 0-9-year-old age group in Kenya, and a higher and lower peak in the 60-69and 30-39-year-old age groups, respectively, in Japan. The most common subtype of Hodgkin's disease in both countries was mixed cellularity, followed by nodular sclerosis, lymphocyte depletion, and lymphocyte predominance. Mixed cellularity showed a significantly high prevalence among Kenyan children nine years of age or younger. Using the in situ hybridization method, EBV-encoded RNA (EBER-1) was detected in 79\% of the Kenyan cases and 59\% of the Japanese cases, with the mixed cellularity subtype showing a strong correlation with EBER-1. There was $100 \%$ positivity in both countries in those less than nine years old. These results suggest that EBV plays a more direct role in the pathogenesis of Hodgkin's diseases in Kenya, especially in cases among young children and also in Japanese children. Environmental and/or genetic factors may have a role, in addition to EBV, in the pathogenesis of Hodgkin's disease, especially in Nagasaki, Japan.
\end{abstract}

Epstein-Barr virus (EBV) infection is known to play an important role in oncogenesis of several neoplasias, in particular, African endemic Burkitt's lymphoma and Chinese nasopharyngeal carcinoma in southeast Asia. ${ }^{1,2}$ Many reports also show that other diseases, such as Hodgkin's disease, ${ }^{3-23}$ gastric cancer, ${ }^{24-26}$ and esophageal cancer, have some relationship with EBV infections. Hodgkin's disease is a malignant lymphoproliferative disorder with characteristic features regarding epidemiology and histopathology. In industrialized countries, this disease shows a bimodal age distribution with peaks in young adults and in the elderly, with a predominance of nodular sclerosis..$^{6-8,10,15,21,27}$ However, in developing countries, such as tropical Africa, central and south America, Hodgkin's disease is seen more frequently in children, with a predominance of mixed cellularity and lymphocyte depletion subtypes. . $^{3,28,29}$

The EBV genome has been detected in patients with Hodgkin's disease by the polymerase chain reaction (PCR), Southern blot analysis, and in situ hybridization methods, and the rates of EBV detection vary depending on the geographic location under study or on the research methods used. ${ }^{4}$ The EBV positivity rate in patients with Hodgkin's disease is reported to be much higher in developing countries, such as Peru, ${ }^{5}$ Honduras, ${ }^{21}$ and Kenya, ${ }^{6,23}$ than in industrialized countries, such as the United States and the European countries. ${ }^{4,6-8}$

We have performed studies to compare the differences of epidemiologic and histologic patterns of Hodgkin's disease and to investigate the presence of EBV in tissues of patients with this disease from the western part of Kenya and $\mathrm{Na}$ gasaki, Japan. We have chosen these areas for the following reasons. 1) The western part of Kenya, especially the basin area along Lake Victoria, is a highly predominant area of EBV-associated African endemic Burkitt's lymphoma. ${ }^{30,31} 2$ ) There are few reports of Hodgkin's disease from sub-Saharan African countries, especially those correlating this disease and EBV. ${ }^{6,23,29}$ 3) Hodgkin's disease is a relatively uncommon disease among the malignant lymphomas in Japan. 4) There are few reports of Hodgkin's disease in association with EBV in Asian countries. ${ }^{9-11}$

\section{MATERIALS AND METHODS}

We studied all consecutive 48 biopsy materials of cases of Hodgkin's disease among the specimens that were submitted for pathologic diagnosis from various hospitals in the western part of Kenya (Western, Nyanza, and Rift Valley provinces: 1985-1995) to the Department of Histopathology, Rift Valley Provincial General Hospital and the 49 cases of Hodgkin's disease recorded at the Cancer Registry of Nagasaki prefecture (1979-1991). This was a retrospective study and specimens used were archival specimens. This study was authorized by the Government of Kenya (research permit no. OP.13/001/8C224/36) and was reviewed and approved by the Committee of Cancer Registry of Nagasaki Prefecture. In cases where more than one biopsy was taken from a patient, only the first sample was used. We divided the cases into three age groups: children (0-14 years old), young adults (15-44 years old), and adults ( $\geq 45$ years old). The data on the age of 19 cases from Kenya were not available.

Histologic evaluation. Specimens were fixed in $10 \%$ formalin saline solution, embedded in paraffin, sectioned, and stained with hematoxylin and eosin, periodic acid-Schiff, silver impregnation, and Mallory's stain. Hodgkin's disease was diagnosed based on results with these histologic stains along with immunohistochemical staining using monoclonal antibodies CD15 and CD30. According to the Rye classification, ${ }^{32}$ all cases were classified into four histologic subtypes (lymphocyte predominance, mixed cellularity, nodular sclerosis, and lymphocyte depletion) by three pathologists (MK, KT, and HI). 


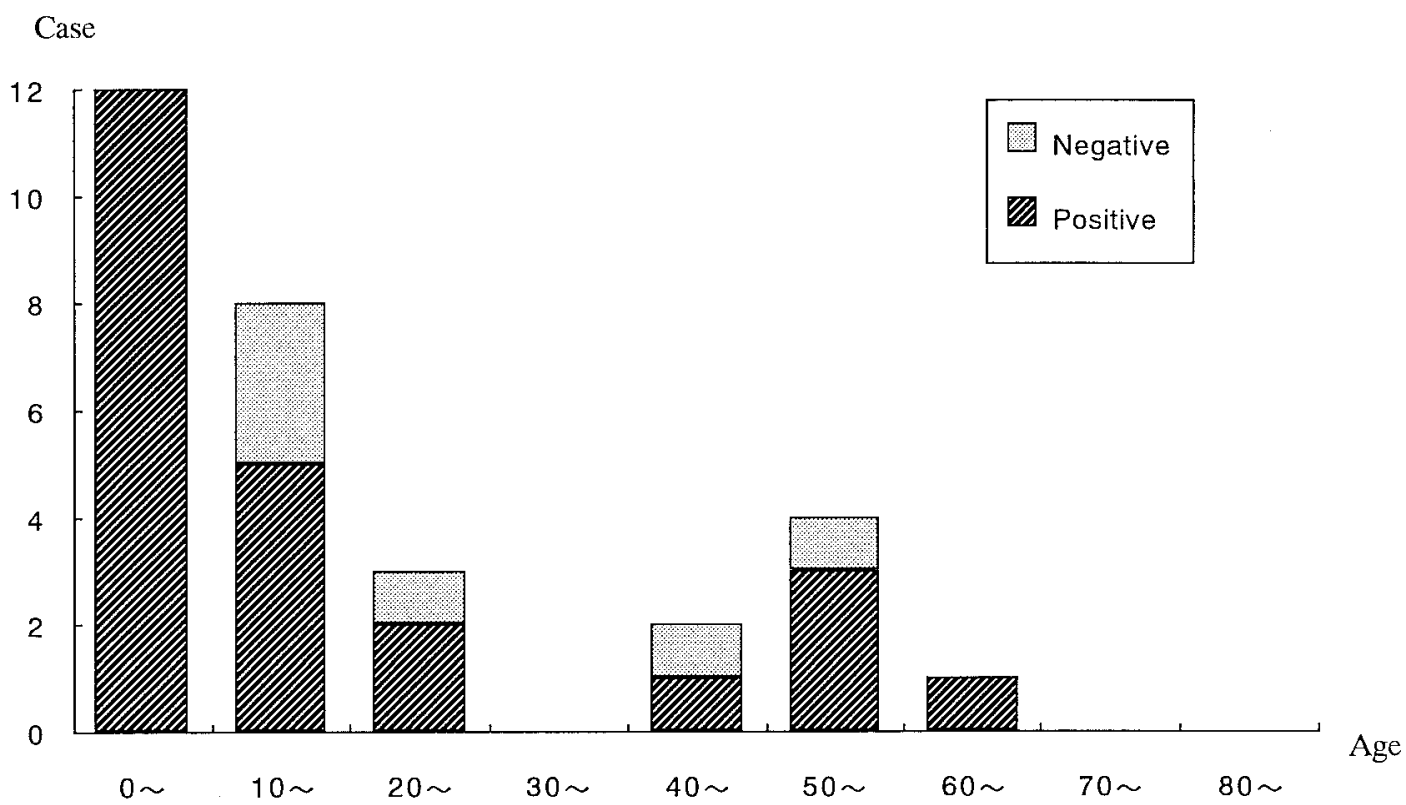

FIgURE 1. Age (years) distribution of Epstein-Barr virus-encoded RNA positivity of Hodgkin's disease in Kenya.

In situ hybridization. This method, which uses a digoxigenin-labeled EBV-encoded RNA (EBER-1) 30-base oligonucleotide probe ${ }^{24-26}$ (kindly provided by Dr. M. Tokunaga, Kagoshima City Hospital, Kagoshima, Japan), was performed on specimens from 48 cases from Kenya and 46 cases from Nagasaki. Briefly, 5- $\mu \mathrm{m}$ sections of formalinfixed, paraffin-embedded tissue were mounted on aminopropyl-triethoxy silane (APS)-coated slides, deparaffinized, rehydrated, predigested with pronase (protease, lot 45H00841; Sigma, St. Louis, MO), and hybridized overnight at $37^{\circ} \mathrm{C}$ with $0.5 \mu \mathrm{g}$ of digoxigenin-labeled probe. After washing with $0.5 \times \mathrm{SSC}(0.075 \mathrm{M} \mathrm{NaCl}, 0.0075 \mathrm{M}$ sodium citrate), hybridization was detected by an antidigoxigenin antibodyalkaline phosphatase conjugate (code 1093274 150; Boehringer Mannheim, Mannheim, Germany), then counterstained with methyl green. Lymph node sections from a patient with infectious mononucleosis were used as a positive control and a sense probe for EBER-1 was used as a negative control for each procedure.

Immunohistochemistry. Immunohistochemical staining was performed on 48 cases from Kenya and 46 cases from Nagasaki. The following monoclonal antibodies were used: CD15 (C3D-1, lot 124; Dako, Glostrup, Denmark), CD30 (Ber-H2, lot 044; Dako), and EBV-encoded latent membrane protein (LMP-1) (CS1-4, lot 013; Dako). ${ }^{8,17,19-21,33,34}$ All sections were cut at a thickness of $5 \mu \mathrm{m}$ and mounted on APScoated slides. After dewaxing with xylene and rehydrating with alcohol, slides were placed in $0.01 \mathrm{M}$ citrate buffer solution and pretreatment procedures to unmask the antigens were performed in a microwave oven for $10 \mathrm{~min}$. Containers were cooled at room temperature for $20 \mathrm{~min}$. Endogenous peroxidase activity was blocked with $3 \%$ hydrogen peroxide. The sections were then washed in phosphate-buffered saline (PBS) and processed for immunohistochemistry with a labeled streptavidin biotin-based method (LSAB kit, lot 0754; Dako). After incubation with a second blocking reagent for $5 \mathrm{~min}$, primary antibody was applied and incubated at
$4{ }^{\circ} \mathrm{C}$ overnight. Sections were washed three times in PBS (5 $\mathrm{min} / \mathrm{wash}$ ) and the secondary antibody was applied for 10 min. After the sections were rinsed three times in PBS (5 min/wash), streptavidin-peroxidase reagent was applied and incubated for $10 \mathrm{~min}$. The sections were washed three times in PBS (5 min/wash) and reactions were developed with diaminobenzidine-activated with hydrogen peroxide. Sections were then washed with water, counterstained with hematoxylin, dehydrated, and mounted. Sections from a patient with infectious mononucleosis were used as a positive control and sections from a patients with reactive lymphadenitis were used as a negative control.

Statistical analysis. A statistical comparison was performed for EBER-1 positivity rates between the cases in Kenya and those in Nagasaki using the chi-square test. A $P$ value of 0.05 was chosen as the significance level.

\section{RESULTS}

Age and sex. The mean age of the patients from Kenya was 21 years (range $=4-65$ ) and that of the patients from Nagasaki was 52 years (range $=6-86$ ). Hodgkin's disease showed a bimodal age distribution in both countries, with the first distinct peak in the 0-9-year-old age group and a second lower peak in the 50-59-year-old age group in $\mathrm{Ke}$ nya, and a higher peak in the 60-69-year-old age group and a lower peak in the 30-39-year-old age group in Nagasaki (Figures 1 and 2). The male to female ratio was almost 2:1 in both countries.

Histologic classification. The most common histologic subtype in both countries was mixed cellularity, followed by nodular sclerosis, lymphocyte depletion, and lymphocyte predominance (Tables 1 and 2). However, among the subtypes, the prevalence of mixed cellularity was significantly higher among Kenyan children nine years of age or younger. In both countries, the mean age of patients with nodular sclerosis was lower than that of any subtype of Hodgkin's 
Case

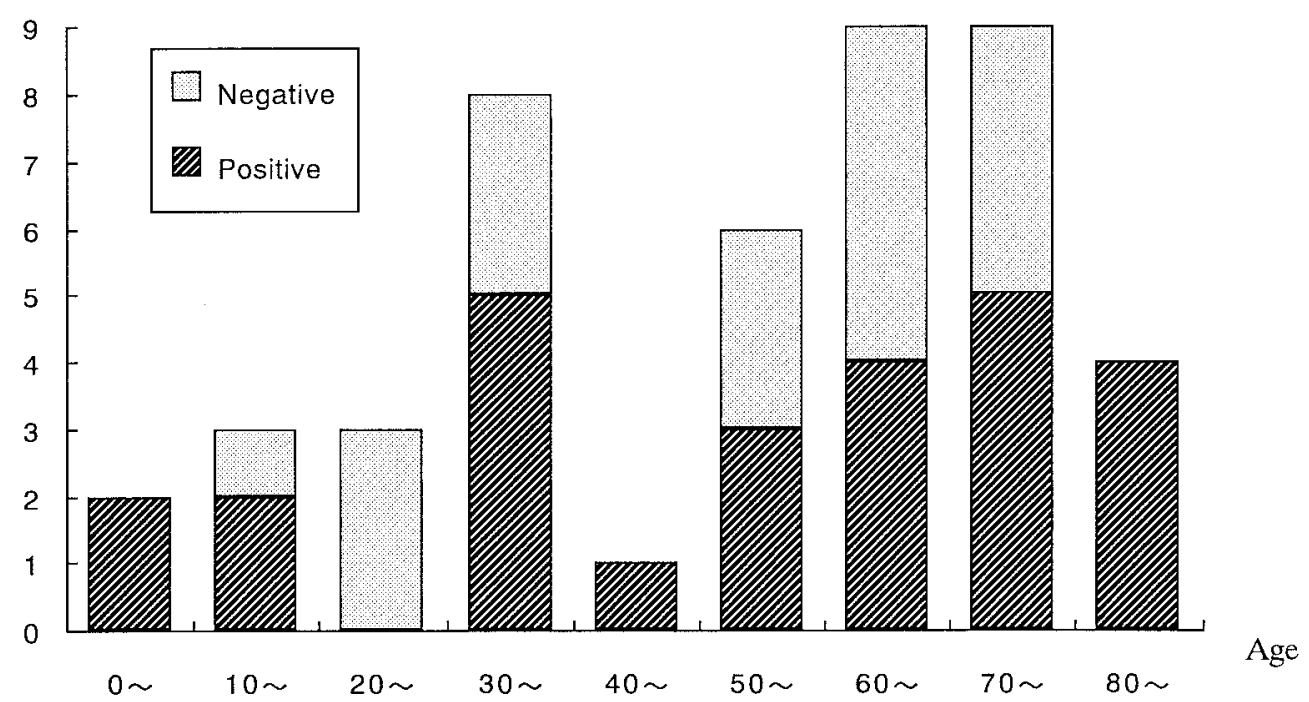

FIgURE 2. Age (years) distribution of Epstein-Barr virus-encoded RNA positivity of Hodgkin's disease in Nagasaki, Japan.

disease. Nodular sclerosis was evenly distributed between the sexes, which differed from the other subtypes.

Epstein-Barr virus-encoded RNA. The EBER-1 positivity rates in Hodgkin's disease tissue determined by in situ hybridization were $79 \%$ in Kenya and 59\% in Nagasaki (Figure $3 \mathrm{~A})$. The rate in Kenya was significantly higher than that in Nagasaki $(P<0.05)$. In children nine years of age or younger, the positivity rate was $100 \%$ in both countries, and in Kenya, $89 \%$ of the subjects $<15$ years of age were EBER-1 positive (Tables 3 and 4). Compared with the young adult group, children ( $0-14$ years old) and adults ( $\geq 45$ years old) showed higher rates of EBER-1 positivity in both countries, and Hodgkin's disease in these two groups was more likely to be associated with EBV infection. With regard to histologic subtypes, there was a strong correlation between EBER-1 positivity and mixed cellularity ( $85 \%$ in Kenya and $67 \%$ in Nagasaki) and lymphocyte depletion (80\% in Kenya and $71 \%$ in Nagasaki); however, the nodular sclerosis subgroup had a lower correlation with EBV infection (57\% in Kenya and 36\% in Nagasaki). A small number of cases of Hodgkin's disease had EBV genomes in small lymphocytes.

Latent membrane protein-1. This protein was expressed in $85 \%$ of the cases from Kenya and $61 \%$ of the cases from Nagasaki (Figure 3B). One case in Kenya was EBER-1 positive and LMP-1 negative and four were EBER-1 negative and LMP-1 positive. In Nagasaki, three cases were EBER-

TABLE 1

Histologic classification of Hodgkin's disease patients in Kenya

\begin{tabular}{|c|c|c|c|c|c|}
\hline \multirow{2}{*}{$\begin{array}{l}\text { Histologic } \\
\text { type** }\end{array}$} & \multicolumn{2}{|c|}{ Sex } & \multicolumn{2}{|c|}{ Total } & \multirow{2}{*}{$\begin{array}{c}\text { Mean age } \\
\text { (years) }\end{array}$} \\
\hline & Male & Female & No. & $\%$ & \\
\hline LP & 2 & 1 & 3 & 6.2 & 19.5 \\
\hline MC & 23 & 10 & 33 & 68.8 & 22.3 \\
\hline NS & 4 & 3 & 7 & 14.6 & 12.0 \\
\hline LD & 4 & 1 & 5 & 10.4 & 30.0 \\
\hline
\end{tabular}

$=$ lymphocyte depletion.
1 positive and LMP-1 negative, and four were EBER-1 negative and LMP-1 positive.

\section{DISCUSSION}

Kenya is located in the lymphoma belt along the low latitudinal zone of the African continent. ${ }^{31}$ The western part of Kenya shows an especially high frequency of EBV-related endemic Burkitt's lymphoma. ${ }^{30}$ In our study, Hodgkin's disease in Kenya demonstrated the typical age distribution seen in other developing countries; a distinct peak in childhood, with a predominance of the mixed cellularity subtype, and the lower peak in adult groups. ${ }^{6,28,29}$ The series of patients with Hodgkin's disease from Nagasaki showed a higher peak in the adult group and a lower peak in the young adult group, which was relatively similar to data from other industrialized countries. ${ }^{10,14,15,27}$

The expression rate of the EBV genome in Hodgkin and Reed-Sternberg (RS) cells of tissues from patients with Hodgkin's disease ranges from $26 \%$ to $100 \%$, depending on geographic location or the method that researchers used, such as PCR and in situ hybridization methods or Southern blot analysis. ${ }^{3-12,16,18-23}$ Relatively higher positive rates have been reported from Central and South America and Africa, examples of which are $100 \%$ in Honduras, ${ }^{21}$ 94\% in Peru, ${ }^{5}$ $72 \%$ in Algeria, ${ }^{7}$ and $92 \%$ in Kenya. ${ }^{6}$ Lower rates $(26-48 \%$ ) have been reported from the United States and European

TABLE 2

Histologic classification of Hodgkin's disease patients in Nagasaki

\begin{tabular}{|c|c|c|c|c|c|}
\hline \multirow{2}{*}{$\begin{array}{c}\text { Histologic } \\
\text { type* }\end{array}$} & \multicolumn{2}{|c|}{ Sex } & \multicolumn{2}{|c|}{ Total } & \multirow{2}{*}{$\underset{\text { (years) }}{\text { Mean age }}$} \\
\hline & Male & Female & No. & $\%$ & \\
\hline LP & 3 & 4 & 7 & 14.3 & 55.4 \\
\hline $\mathrm{MC}$ & 16 & 4 & 20 & 40.8 & 48.7 \\
\hline NS & 8 & 7 & 15 & 30.6 & 44.1 \\
\hline LD & 4 & 3 & 7 & 14.3 & 76.1 \\
\hline
\end{tabular}




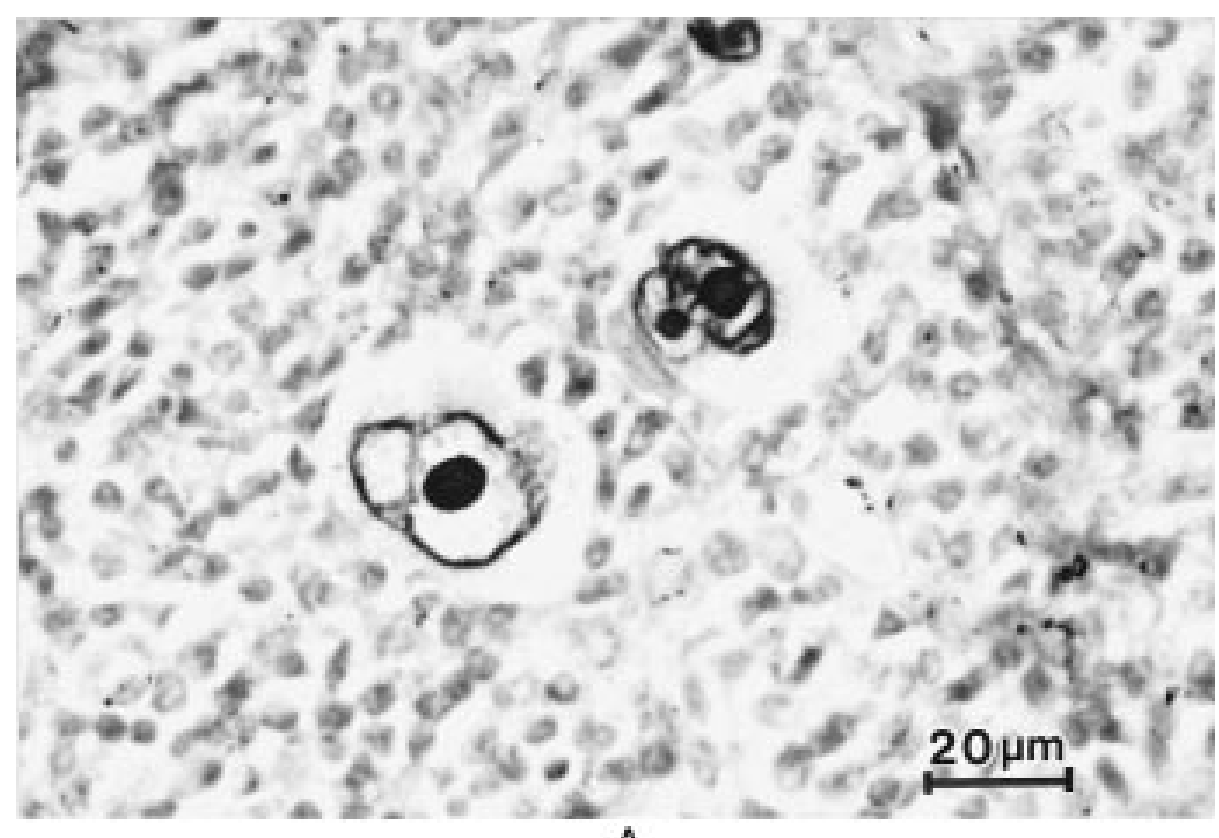

A

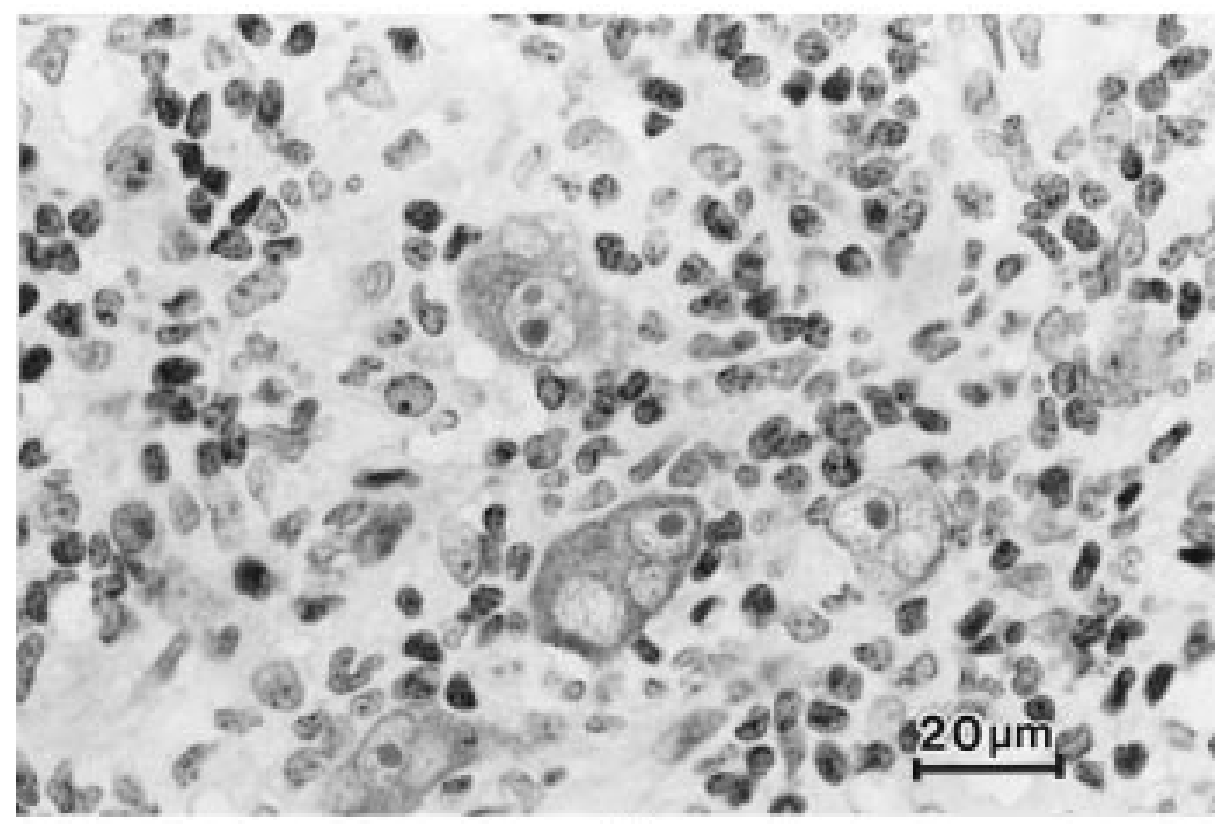

B

FIGURE 3. A, Epstein-Barr virus-encoded RNA in situ hybridization showing strong signals in nuclei of Reed-Sternberg (RS) cells and their variants (in situ hybridization with methyl green, magnification $\times 400$ ). B, immunohistochemical staining of latent membrane protein-1 (LMP-1) showing strong staining in the membrane and cytoplasm of RS cells and their variants (LMP-1 immunohistochemical staining, magnification $\times 400$ ).

countries ${ }^{4,6-8,12}$ and intermediate rates (64-76\%) from Asian countries. ${ }^{9-11}$ Among the several methods that detect EBV, the PCR is more sensitive than the others. However, one disadvantage of the PCR is that false-positive results can easily be obtained when the case harbors the virus in nonneoplastic lymphoid cells. One advantage of in situ hybridization is that it definitively localizes virus RNA in the neoplastic cells morphologically. 3,4,7,10-13,17 Therefore, we used in situ hybridization in our study to detect the EBV genome in tissues from patients with Hodgkin's disease. Strong signals were revealed in the nuclei of RS cells and their variants in $79 \%$ of the cases from Kenya and in 59\% from Nagasaki.

As in many previous reports, $3,5-9,11-14,18,20,22,23$ our results showed a strong association between EBV and the mixed cellularity and lymphocyte depletion histologic subtypes. In the mixed cellularity subtype, EBER-1 positivity was $85 \%$ in Kenya and $67 \%$ in Nagasaki, while that for the lymphocyte depletion subtype was $80 \%$ in Kenya and $71 \%$ in $\mathrm{Na}-$ 
TABLE 3

Epstein-Barr virus (EBV)-encoded RNA positivity of Hodgkin's disease patients in Kenya

\begin{tabular}{|c|c|c|c|c|c|c|}
\hline \multirow[b]{2}{*}{ Group $\dagger$} & \multirow[b]{2}{*}{ No. of cases } & \multicolumn{5}{|c|}{ Histologic subtype* } \\
\hline & & LP & $\mathrm{MC}$ & NS & LD & $\mathrm{EBV}+(\%)$ \\
\hline \multicolumn{7}{|l|}{ Children } \\
\hline$(<15)$ & 18 & $1 / 1$ & $12 / 13$ & $2 / 3$ & $1 / 1$ & 16/18 (89) \\
\hline$(\leq 9)$ & 12 & $0 / 0$ & 9/9 & $2 / 2$ & $1 / 1$ & $12 / 12(100)$ \\
\hline \multicolumn{7}{|l|}{ Young adults } \\
\hline$(15-44)$ & 8 & $0 / 1$ & $3 / 3$ & $0 / 2$ & $1 / 2$ & $4 / 8 \quad(50)$ \\
\hline \multicolumn{7}{|l|}{ Adults } \\
\hline$(\geq 45)$ & 6 & 0/0 & $4 / 5$ & $0 / 0$ & $1 / 1$ & $5 / 6 \quad(83)$ \\
\hline $\mathrm{EBV}+(\%)$ & & $1 / 2(50)$ & $19 / 21(90)$ & $2 / 5(40)$ & $3 / 4(75)$ & $25 / 32(78)$ \\
\hline $\mathrm{EBV}+(\%) \ddagger$ & & $2 / 3(67)$ & $28 / 33(85)$ & 4/7 (57) & $4 / 5(80)$ & $38 / 48$ (79) \\
\hline
\end{tabular}

* For definitions of abbreviations, see Table 1 .

$\dagger$ Age group values are in years.

$\ddagger$ Includes age unknown group.

gasaki. On the other hand, of the four subtypes, nodular sclerosis had the lowest rate of EBER-1 positivity: $57 \%$ in Kenya and $36 \%$ in Nagasaki.

Interestingly, our results showed higher EBER-1 positivity in children in both Kenya (89\%) and Nagasaki (100\%) compared with the other groups. Strikingly, EBER-1 positivity was $100 \%$ in those nine years of age and less in both countries. This phenomenon has already been reported by several investigators, and our results support these findings. ${ }^{18-23}$ The adult group ( $\geq 45$ years old) had the second highest rate of EBER-1 positivity, with young adult groups having the lowest rate in both countries. ${ }^{10,13,14}$ In our study, certain histologic subtypes seemed to be predominant in specific age groups that showed EBER-1 positivity. Children and adults showed a predominance of mixed cellularity, while young adults showed a predominance of nodular sclerosis. Mixed cellularity had a strong association with EBV, while nodular sclerosis had the lowest correlation with EBV. This result is similar to those of many previous reports; $3,8,10,13,14,20-22$ however, Leoncini and others noted a high expression of EBER$1 / 2$ in Kenyan cases with nodular sclerosis. ${ }^{6}$ Since these investigators used the REAL classification of Hodgkin's disease subtyping, ${ }^{35}$ further study is needed to confirm these data.

The reason for the difference in these epidemiologic features has not yet been determined; however, it may be speculated that the environment of poor economic conditions and poor hygiene in which many African children live causes a secondary immunodeficiency status. ${ }^{15,28}$
Latent membrane protein- 1 is known to have transforming activity and has also been reported to be an oncogenic protein that protect cells from programmed cell death. ${ }^{4,8,13,17,19,21,34}$ Although the precise role of LMP-1 is still obscure, strong staining of LMP-1 in the membrane and cytoplasm of Hodgkin and RS cells from tissues of patients with Hodgkin's disease in our study indicates that EBV plays an important role in the pathogenesis of this disease with its oncogenic potential. ${ }^{4,5,7-9,11-14,16-23}$ We have also observed four cases that were EBER-1 positive and LMP-1 negative and eight cases that were EBER-1 negative and LMP-1 positive. The group of individuals who were EBER-1 positive and LMP-1 negative can be explained by the lower sensitivity of the immunohistochemical method compared with in situ hybridization. ${ }^{5,7}$ There is a possibility that the group of eight cases who were EBER-1 negative and LMP-1 positive harbor a type 2 strain in the neoplastic cells. This is consistent with the results of several investigators, ${ }^{6,7,10,12,18,23}$ who detected EBV type 2 strains in cases of Hodgkin's disease.

The results of our study suggest that EBV plays a more direct role in the pathogenesis of Hodgkin's disease in Kenya than in Nagasaki, and that this disease in children is more strongly linked with EBV infection than in adults. In addition to that of EBV, environmental and/or genetic factors also have a role in the pathogenesis of Hodgkin's disease, especially in Nagasaki, Japan.

Acknowledgments: We thank Dr. M. Tokunaga for technical suggestions, Professor T. Ikeda, Dr. N. Tsuda, Dr. M. Kishikawa, Dr. S.

TABLE 4

Epstein-Barr virus (EBV)-encoded RNA positivity of Hodgkin's disease patients in Nagasaki

\begin{tabular}{|c|c|c|c|c|c|c|}
\hline \multirow[b]{2}{*}{ Group $\dagger$} & \multirow[b]{2}{*}{ No of cases } & \multicolumn{5}{|c|}{ Histologic subtype* } \\
\hline & & LP & $\mathrm{MC}$ & NS & LD & $\mathrm{EBV}+(\%)$ \\
\hline \multicolumn{7}{|l|}{ Children } \\
\hline$(<15)$ & 4 & $0 / 0$ & $3 / 3$ & $1 / 1$ & $0 / 0$ & $4 / 4 \quad(100)$ \\
\hline$(\leq 9)$ & 2 & $0 / 0$ & $2 / 2$ & $0 / 0$ & $0 / 0$ & $2 / 2 \quad(100)$ \\
\hline \multicolumn{7}{|l|}{ Young adult } \\
\hline$(15-44)$ & 13 & $2 / 2$ & $3 / 4$ & $1 / 7$ & $0 / 0$ & $6 / 13(46)$ \\
\hline \multicolumn{7}{|l|}{ Adult } \\
\hline$(\geq 45)$ & 28 & $2 / 4$ & $6 / 11$ & $3 / 6$ & $5 / 7$ & $16 / 28(57)$ \\
\hline $\mathrm{EBV}+(\%)$ & & $4 / 6(67)$ & $12 / 18(67)$ & $5 / 14(36)$ & $5 / 7(71)$ & $27 / 46(59) \ddagger$ \\
\hline
\end{tabular}

* For definitions of abbreviations, see Table 1

$\dagger$ Age group values are in years.

$\ddagger$ Includes one age unknown case. 
Fujii, Dr. K. Kawai, and Dr. O. Takahara for providing study materials, and Dr. M. Hayata for providing clinical data on Hodgkin's disease from the Nagasaki Tumor Registry.

Financial support: This study was supported in part by a grant-in aid for the international scientific research program (field research) of the Ministry of Education, Science, Sports and Culture of Japan (research no. 06041086 and 090041188).

Authors' addresses: Masako Kusuda, Kan Toriyama, and Hideyo Itakura, Department of Pathology, Institute of Tropical Medicine, Nagasaki University, 1-12-4 Sakamoto, Nagasaki 852-8523, Japan. Noah O. Kamidigo, Department of Histopathology, Rift Valley Provincial General Hospital, PO Box 71, Nakuru, Kenya.

Reprint requests: Kan Toriyama, Department of Pathology, Institute of Tropical Medicine, Nagasaki University, 1-12-4 Sakamoto, Nagasaki 852-8523, Japan.

\section{REFERENCES}

1. zur Hausen H, Schulte-Holthausen H, Klein G, Henle W, Henle G, Clifford P, Santesson L, 1970. EBV DNA in biopsies of Burkitt tumours and anaplastic carcinomas of the nasopharynx. Nature 228: 1056-1058.

2. Dickens P, Srivastava G, Loke SL, Chan CW, Liu YT, 1992. Epstein-Barr virus DNA in nasopharyngeal carcinomas from Chinese patients in Hong Kong. J Clin Pathol 45: 396-397.

3. Zarate-Osorno A, Roman LN, Kingma DW, Meneses-Garcia A, Jaffe ES, 1995. Hodgkin's disease in Mexico. Prevalence of Epstein-Barr virus sequences and correlations with histologic subtype. Cancer 75: 1360-1366.

4. Armstrong AA, Weiss LM, Gallagher A, Jones DB, Krajewski AS, Angus B, Brown G, Jack AS, Wilkins BS, Onions DE, Jarrett RF, 1992. Criteria for the definition of Epstein-Barr virus association in Hodgkin's disease. Leukemia 6: 869-874.

5. Chang KL, Albujar PF, Chen YY, Johnson RM, Weiss LM, 1993. High prevalence of Epstein-Barr virus in the ReedSternberg cells of Hodgkin's disease occurring in Peru. Blood 81: 496-501.

6. Leoncini L, Spina D, Nyong'o A, Abinya O, Minacci C, Disanto A, De Luca F, De Vivo A, Sabattini E, Poggi S, Pileri S, Tosi P, 1996. Neoplastic cells of Hodgkin's disease show differences in EBV expression between Kenya and Italy. Int $J$ Cancer 65: 781-784.

7. Belkaid MI, Briere J, Djebbara Z, Beldjord K, Andrieu JM, Colonna P, 1995. Comparison of Epstein-Barr virus markers in Reed-Sternberg cells in adult Hodgkin's disease tissues from an industrialized and a developing country. Leuk Lymphoma 17: 163-168.

8. Pinkus GS, Lones M, Shintaku IP, Said JW, 1994. Immunohistochemical detection of Epstein-Barr virus-encoded latent membrane protein in Reed-Sternberg cells and variants of Hodgkin's disease. Mod Pathol 7: 454-461.

9. Tomita Y, Ohsawa M, Kanno H, Hashimoto M, Ohnishi A, Nakanishi H, Aozasa K, 1996. Epstein-Barr virus in Hodgkin's disease patients in Japan. Cancer 77: 186-192.

10. Chan JKC, Yip TTC, Tsang WYW, Lau WH, Wong CSC, Ma VWS, 1995. Detection of Epstein-Barr virus in Hodgkin's disease occurring in an oriental population. Hum Pathol 26: 314-318.

11. Park CS, Juhng SW, Brigati DJ, Montone KT, 1994. Analysis of Epstein-Barr virus in Hodgkin's disease: Experience of a single university hospital in Korea. J Clin Lab Anal 8: 412-417.

12. Khan G, Norton AJ, Slavin G, 1993. Epstein-Barr virus in Hodgkin disease. Relation to age and subtype. Cancer 71: 3124-3129.

13. Khan G, Coates PJ, 1994. The role of Epstein-Barr virus in the pathogenesis of Hodgkin's disease. J Pathol 174: 141149.

14. Jarrett AF, Armstrong AA, Alexander E, 1996. Epidemiology of EBV and Hodgkin's lymphoma. Ann Oncol 7 (suppl 4): $5-10$
15. Mueller N, 1991. An epidemiologist's view of the new molecular biology findings in Hodgkin's disease. Ann Oncol 2 (suppl 2): 23-28.

16. Kaczorowski S, Kaczorowska M, Christensson B, 1994. Expression of EBV encoded latent membrane protein 1(LMP1) and bcl-2 protein in childhood and adult Hodgkin's disease: Application of microwave irradiation for antigen retrieval. Leuk Lymphoma 13: 273-283.

17. Niedobitek G, 1996. The role of Epstein-Barr virus in the pathogenesis of Hodgkin's disease. Ann Oncol 7(suppl 4): $11-17$.

18. Kanavaros P, Sakalidou A, Tzardi M, Darivianaki K, Delides G, Kazlaris E, Kalmanti M, 1994. Frequent detection of Epstein-Barr virus(EBV), EBEB transcripts and latent membrane protein-1(LMP-1) in tumor cells in Hodgkin's disease arising in childhood. Pathol Res Pract 190: 10261030

19. Weinreb M, Day PJR, Murray PG, Raafat F, Crocker J, Parkes SE, Coad NAG, Jones JT, Mann JR, 1992. EpsteinBarr virus(EBV) and Hodgkin's disease in children: Incidence of EBV latent membrane protein in malignant cells. J Pathol 168: 365-369.

20. Preciado MV, Matteo ED, Diez B, Grinstein S, 1995. Epstein-Barr virus(EBV) latent membrane protein(LMP) in tumor cells of Hodgkin's disease in pediatric patients. Med Pediatr Oncol 24: 1-5.

21. Ambinder RF, Browning PJ, Lorenzana I, Leventhal BG, Cosenza H, Mann RB, MacMahon EME, Medina R, Cardona V, Grufferman S, Olshan A, Levin A, Petersen EA, Blattner W, Levine PH, 1993. Epstein-Barr virus and childhood Hodgkin's disease in Honduras and the United States. Blood 81: 462-467.

22. Armstrong AA, Alexander FE, Paes RP, Morad NA, Gallagher A, Krajewski AS, Jones DB, Angus B, Adams J, Cartwright RA, Onions DE, Jarrett RF, 1993. Association of Epstein-Barr virus with pediatric Hodgkin's disease. Am J Pathol 142: 1683-1688.

23. Weinreb M, Day PJR, Niggli F, Green EK, Nyong'o AO, Othieno-Abinya NA, Riyat MS, Raafat F, Mann JR, 1996. The consistent association between Epstein-Barr virus and Hodgkin's disease in children in Kenya. Blood 87: 3828 3836 .

24. Tokunaga M, Land CE, Uemura Y, Tokudome T, Tanaka S, Sato E, 1993. Epstein-Barr virus in gastric carcinoma. Am J Pathol 143: 1250-1254.

25. Tokunaga M, Uemura $\mathrm{Y}$, Tokudome T, Ishidate T, Masuda $\mathrm{H}$, Okazaki E, Kaneko K, Naoe S, Ito M, Okamura A, Shimada A, Sato E, Land CE, 1993. Epstein-Barr virus related gastric cancer in Japan: A molecular patho-epidemiological study. Acta Pathol Jpn 43: 574-581.

26. Shibata D, Tokunaga M, Uemura Y, Sato E, Tanaka S, Weiss LM, 1991. Association of Epstein-Barr virus with undifferenciated gastric carcinomas with intense lymphoid infiltration. Am J Pathol 139: 469-474.

27. Merk K, Bjorkholm M, Rengifo E, Gavilondo J, Holm G, Rivas H, 1990. Epidemiological study of Hodgkin's disease in Cuba and Sweden. Oncology 47: 246-250.

28. Jacobs P, 1991. The malignant lymphoma in Africa. Hematol Oncol Clin North Am 5: 953-982.

29. Riyat MS, 1992. Hodgkin's disease in Kenya. Cancer 69: 1047-1051.

30. Makata AM, Toriyama K, Kamidigo NO, Eto H, Itakura H, 1996. The pattern of pediatric solid malignant tumors in western Kenya, East Africa, 1979-1994: an analysis based on histopathologic study. Am J Trop Med Hyg 54: 343347.

31. Burkitt DP, 1970. Geographical distribution. Burkitt DP, Wright DH, ed. Burkitt's Lymphoma. Edinburgh and London: E \& S Livingstone, 186-197.

32. Correa P, O'Conor GT, Berard CW, Axtell LM, Myers MH, 1973. International comparability and reproducibility in histologic subclassification of Hodgkin's disease. J Natl Cancer Inst 50: 1429-1435.

33. Murray PG, Young LS, Rowe M, Crocker J, 1992. Immu- 
nohistochemical demonstration of the Epstein-Barr virusencoded latent membrane protein in paraffin sections of Hodgkin's disease. J Pathol 166: 1-5.

34. Herbst H, Dallenbach F, Hummel M, Niedobitek G, Pileri S, Muller-Lantzsch N, Stein H, 1991. Epstein-Barr virus latent membrane protein expression in Hodgkin and ReedSternberg cells. Proc Natl Acad Sci USA 88: 4766-4770.
35. Harris NL, Jaffe ES, Stein H, Banks BM, Chan JKC, Cleary ML, Delsol G, De Wolf-Peeters C, Falini B, Gatter KC, Grogan TM, Isaacson PG, Knowles DM, Mason DY, Muller-Hermelink HK, Pileri SA, Piris MA, Ralfkiaer E, Warnke RA, 1994. A revised European-American classification of lymphoid neoplasms: a proposal from the International Lymphoma Study Group. Blood 84: 1361-1392. 